Sains Malaysiana 50(2)(2021): 449-460

http://dx.doi.org/10.17576/jsm-2021-5002-16

\title{
Polarity Difference and the Presence of Phytoestrogen Compounds Affecting Estrogenic Activity of Peperomia pellucida Extracts
}

(Perbezaan Kekutuban dan Kehadiran Sebatian Fitoestrogen yang Mempengaruhi Aktiviti Estrogen Ekstrak Peperomia pellucida)

\author{
I Gusti Agung Ayu Kartika, Muhamad Insanu, Catur Riani, Kyu Hyuck Chung, I Ketut Adnyana*
}

\begin{abstract}
Peperomia pellucida (L.) Kunth has been studied as an anti-osteoporotic agent. However, there is no report about its estrogenic activity, which is important for its anti-osteoporotic activity. Thus, the aim of this research was to study the estrogenic potency of $\mathrm{P}$. pellucida extracts. The estrogenic activity of $\mathrm{P}$. pellucida extracts (n-hexane, ethyl acetate, ethanol, and water extracts) was studied using E-screen assay and confirmed with a molecular docking simulations. Further, the presence of phytoestrogen compounds was identified using thin layer chromatography (TLC), TLC densitometry, and high performance liquid chromatography. The n-hexane, ethyl acetate, and ethanol extracts at a concentration of $0.1 \mu \mathrm{g} \mathrm{mL}^{-1}$ exhibited a partial agonist effect, whereas the water extract showed full agonist effect at the similar concentration. This activity was produced through a classical ligand-dependent mechanism similar to estradiol. $N$-hexane and ethyl acetate extracts showed antiestrogenic activity. The TLC chromatogram evidently depicted the presence of quercetin and stigmasterol in the $n$-hexane and ethyl acetate extracts. Apigenin and apigetrin at concentrations of $0.239 \pm 0.076$ and $1.063 \pm 0.156 \mu \mathrm{g} \mathrm{mg}^{-1}$ extract, respectively, were present in the water extract. A docking study on estrogen receptors confirmed that apigetrin prefer to produce estrogenic activity, whereas the other compounds can produce both estrogenic and antiestrogenic activity. Hence, we suggest that the bioactive compounds in the water extract are flavonoids, such as apigenin and apigetrin. In summary, the water extract is recommended to be used as an estrogenic agent.
\end{abstract}

Keywords: Apigenin; apigetrin; docking; estrogenic; extract; Peperomia pellucida

\section{ABSTRAK}

Peperomia pellucida (L.) Kunth telah dikaji sebagai agen anti-osteoporosis. Walau bagaimanapun, tiada laporan mengenai aktiviti estrogennya yang penting untuk aktiviti anti-osteoporosisnya. Oleh itu, tujuan penyelidikan ini adalah untuk mengkaji potensi estrogen ekstrak P. pellucida. Aktiviti estrogen ekstrak P. pellucida (n-heksana, etil asetat, etanol dan ekstrak air) telah dikaji dengan menggunakan ujian E-screen dan disahkan dengan simulasi dok pengimejan. Selanjutnya, sebatian fitoestrogen telah dikenal pasti menggunakan kromatografi lapisan tipis (KLT), KLT densitometri dan kromatografi cecair prestasi tinggi. Ekstrak n-heksana, etil asetat dan etanol pada kepekatan $0.1 \mu \mathrm{g}$ $m L^{-1}$ menunjukkan kesan agonis separa, manakala ekstrak air menunjukkan kesan agonis penuh pada kepekatan yang sama. Aktiviti ini dihasilkan melalui mekanisme ligan klasikyang sama seperti estradiol. Semua ekstrakjuga menunjukkan aktiviti antiestrogenik. Kromatogram KLT jelas menggambarkan kehadiran quersetin dan stigmasterol dalam ekstrak

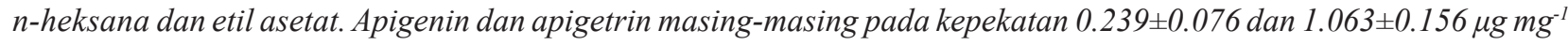
ekstrak, hadir dalam ekstrak air. Kajian dok mengenai reseptor estrogen mengesahkan bahawa apigenin dan apigetrin lebih suka menghasilkan aktiviti estrogenik, sedangkan quersetin dan stigmasterol dapat menghasilkan kedua-dua aktiviti estrogenik dan antiestrogenik. Oleh itu, kami mencadangkan bahawa sebatian bioaktif dalam ekstrak air adalah flavonoid, seperti apigenin dan apigetrin. Ringkasnya, ekstrak air disyorkan untuk digunakan sebagai agen estrogen.

Kata kunci: Apigenin; apigetrin; dok; ekstrak; estrogen; Peperomia pellucida 


\section{INTRODUCTION}

Estrogen is classified as a class of steroid hormones. This hormone holds important roles in the human body and is implicated in many different diseases such as obesity, neurodegenerative diseases, cardiovascular disease, insulin resistance, lupus erythematosus, fibroids, endometriosis, osteoporosis, and cancer (Burns \& Korach 2012).

Estrogen function is mediated by estrogen receptor (ERs), of which there are two distinct and functional ERs called ER $\alpha$ and ER $\beta$. In many tissues, activations of ER $\alpha$ and ER $\beta$ are found to be antagonistic. For instance, in the prostate and the breasts, activation of $E R \alpha$ can promote cell proliferation and survival, whereas ER $\beta$ can suppress it (Nelson et al. 2014; Williams et al. 2008). Also, in the bones, estrogen can induce osteoclast apoptosis via ER $\alpha$ and not ER $\beta$ (Khalid \& Krum 2016). Furthermore, several studies have shown that many chemicals that have estrogenic activity can bind to both types of estrogen receptors (Lecomte et al. 2017).

Phytoestrogens are polyphenolic compounds from plants that may exert estrogenic activity, primarily by binding to ERs. Phytoestrogens can have agonists, partial agonists, or antagonists action toward ERs (Mostrom \& Tim 2018). They act as a selective estrogen receptor modulators (SERMs) similar to tamoxifen, the breast cancer drug. Tamoxifen is biologically active as a partial agonist on selected target tissues including bone, cardiovascular, and the uterus, but is mostly antagonistic in the breast (Peng et al. 2009). This special characteristic makes SERMs one of the drugs of choice in contemporary osteoporosis treatment.

Currently, natural products are widely studied in the search for a new, safe, and economically efficient antiosteoporosis agent. Peperomia pellucida (L.) Kunth is one of the medicinal plants that is of great interest worldwide and has been studied to treat osteoporosis. Recently, this plant was used as a candidate to find an antiosteoporosis agent (Florence et al. 2017; Kartika et al. 2018; Ngueguim et al. 2013; Putri et al. 2016). One compound that exerts estrogen-like properties was unexpectedly found together with some compounds that have the opposite effect from the ethanol extract of P. pellucida by Xu et al. (2006) in their study to find anticancer agents. The finding raises a great curiosity for further research on the estrogenic activity profile of this plant.

Thus far, there are no data available about the estrogenic effect from $P$. pellucida extracts. Considering the need of more supporting data for antiosteoporosis research specifically, the aim of this study is to investigate the estrogenic profile of various $P$. pellucida extracts with different polarities through a robust in vitro assay, detection of phytoestrogen compounds through Thin Layer Chromatography (TLC), Thin Layer ChromatographyDensitometry (TLC-D), and High Performance Liquid Chromatography (HPLC). Also, molecular docking simulations were performed to evaluate the binding affinity of the phytoestrogen compounds present in this plant to ERs. To the best of our knowledge, it is the first report of estrogenic activity potency of $P$. pellucida extracts.

\section{MATERIALS AND METHODS}

\section{MATERIALS}

P. pellucida plant was collected in March and April 2016 from Cagak and Ciater Region, West Java Province, Indonesia. The sample was authenticated by a botanist at the Herbarium Bandungense, Bandung Institute of Technology, Indonesia, referring to document number 705/I1.CO2.2/PL/2016. Extraction solvents including n-hexane, ethyl acetate, ethanol, and aquadest, were provided by CV Fadillah (Bandung Kulon, Indonesia). WST-1 reagent was purchased from Roche (Mannheim, Germany). Penicillin and streptomycin were obtained from GibcoBRL (Grand Island, NY, USA). Dulbecco's Modified Eagle's Medium (DMEM) and trypsin-EDTA were purchased from Invitrogen (Carlsbad, CA). Fetal bovine serum (FBS) was purchased from HyClone (Logan, UT). The other materials, i.e. dimethyl sulfoxide (DMSO), quercetin, stigmasterol, $\mathrm{Na}_{2} \mathrm{CO}_{3}, 17 \beta$-estradiol and tamoxifen, were purchased from Sigma-Aldrich (St. Louis, MO, USA).

\section{EXTRACTION PROCESS}

$\mathrm{N}$-hexane, ethyl acetate, and ethanol extracts were prepared using sequential maceration for $3 \times 24 \mathrm{~h}$. The filtrate was collected and evaporated using a rotary evaporator. Meanwhile, water extracts were prepared separately using a similar method and concentrated using the freeze-drying method.

\section{CELL CULTURE}

The estrogen-sensitive MCF-7 BUS human breast cancer cells used in the E-screen assay were kindly provided by Dr. Soto (Tufts University, MA, USA). Dulbecco's Modified Eagle's Medium supplemented with 5\% fetal bovine serum, penicillin $\left(100\right.$ units $\left.\mathrm{mL}^{-1}\right)$, and streptomycin (100 $\left.\mu \mathrm{g} \mathrm{mL}^{-1}\right)$ were used as growth medium. The cells were incubated in an atmosphere of $5 \% \mathrm{CO}_{2} / 95 \%$ air and saturated humidity at $37^{\circ} \mathrm{C}$. 


\section{CYTOTOXICITY TEST}

Cytotoxicity test using WST-1 cell proliferation assay was conducted prior to the E-screen assay as described by Kim et al. (2015b). At the end of the additional incubation period, all medium was removed and centrifuged at 8000 rpm, room temperature, for $4 \mathrm{~min}$. The absorbance of 80 $\mu \mathrm{L}$ of the supernatant was measured at 440 versus $690 \mathrm{~nm}$ reference wavelength using a VERSAmax microplate reader (Molecular Devices, Sunnyvale, CA).

\section{E-SCREEN ASSAY}

The E-screen assay was conducted according to previous studies (Oh et al. 2008; Perez et al. 1998). To determine the estrogenic activity of the extracts, each extract was added to the experimental medium at a range of concentrations from 0.1 to $10 \mu \mathrm{g} \mathrm{mL}^{-1}$. In order to determine the mechanism of action of the samples, the extracts were combined with tamoxifen $10^{-6} \mathrm{M}$ after which the decrease in activity was compared with estradiol. Also, in order to determine the antiestrogenic activity of the extract samples, estradiol $\left(10^{-11} \mathrm{M}, \mathrm{E}_{2}\right)$ was treated with $0.1 \mu \mathrm{g} / \mathrm{mL}$ of samples. Absorbance was measured using a VERSAmax microplate reader (Molecular Devices, Sunnyvale, CA).

\section{PHYTOCHEMICAL SCREENING}

Phytochemical analysis of the dry plant and extracts was done to evaluate the presence of alkaloids, flavonoids, saponin, tannins, quinones, steroids, and terpenoids. The tests were conducted according to the standard procedures described in the literature (Harborne 1998).

\section{DETERMINATION OF TOTAL FLAVONOID CONTENT}

The total flavonoid content was measured by colorimetric assay. One milliliter of aluminum chloride $10 \%$ and $8 \mathrm{~mL}$ of acetic acid $5 \%$ were added into $1 \mathrm{~mL}$ of sample with a certain concentration and was mixed thoroughly. After $18 \mathrm{~min}$, the absorbance was determined at $413 \mathrm{~nm}$. The mixture consisting of $1 \mathrm{~mL}$ sample and $9 \mathrm{~mL}$ aquadest was used as a control solution. The total flavonoid content was calculated by subtracting the absorbance of the control solution from the absorbance of the samples and then convert the value into $\mu \mathrm{g} \mathrm{QE} / 100 \mathrm{mg}$ using the calibration curve.

\section{DETECTION AND QUANTIFICATION OF PHYTOESTROGEN COMPOUNDS IN THE P. pellucida EXTRACT}

Detection and quantification of phytoestrogen compounds in the P. pellucida extract was performed using TLC, TLC-D and HPLC. Phytosterol (stigmasterol) and flavonoids (apigenin, apigenin 7-O glucoside (apigetrin, cosmosiin), catechin, hyperoside, kaempferol, luteolin, luteolin 7-O glucoside, myricetin, naringenin, orientin, quercetin, and rutin) were used as standard compounds.

First, a TLC analysis was performed on normal phase silica TLC plates (Merck) using certain mobile phases for each standard compound. One $\mu \mathrm{L}$ of $1 \mathrm{mg} \mathrm{mL}^{-1}$ methanolic solutions of standard phytoestrogen compounds and 10 $\mu \mathrm{m} / \mathrm{mL}$ investigated extracts were spotted on the normal phase silica TLC plates, and one-dimensional TLC analysis was performed. The elution results were observed under UV light at 254 and $366 \mathrm{~nm}$ before and after spraying with $10 \%$ sulfuric acid, $\mathrm{AlCl}_{3} 5 \%$ or sitroborat reagent.

A TLC-D analysis was performed on $4 \times 8 \mathrm{~cm}$ aluminum plates coated with Si60 silica gel (Merck). Flavonoid standard and extract sample solutions were applied to the plates as $5-\mathrm{mm}$ bands, $10 \mathrm{~mm}$ from the bottom edge of the plate, using a Linomat sample applicator. The application volume was $5 \mu \mathrm{L}$ for the extract at $50000 \mathrm{ppm}$ and $1 \mu \mathrm{L}$ for the flavonoid standard at 500 $\mathrm{ppm}$. Plates were developed to a distance of $6 \mathrm{~cm}$ at room temperature. Aluminium chloride was used as a spray reagent. Detection was performed using a densitometer Camag (Switzerland) at $366 \mathrm{~nm}$

HPLC was used to determine flavonoid compounds in the extracts. Each standard compound was prepared at $500 \mathrm{ppm}$ and the extracts at $20000 \mathrm{ppm}$ in methanol. Twenty $\mu \mathrm{L}$ samples were injected into the HPLC apparatus. Separation was carried out through column ( $5 \mu \mathrm{m} ; 4.6 \times 250 \mathrm{~mm}$, Kitenex) with diode-array detector. Solvent A (0.05\% trifluoroacetic acid) and solvent B $(0.038 \%$ trifluoroacetic acid in $83 \%$ acetonitrile $(\mathrm{v} / \mathrm{v})$ with the following gradient: $0-5 \mathrm{~min}, 15 \% \mathrm{~B}$ in A, 5-10 min, $70 \% \mathrm{~B}$ in $\mathrm{A}, 10-15 \mathrm{~min}, 70 \% \mathrm{~B}$ in A were used for separation. The flow rate was $1 \mathrm{~mL} \mathrm{~min}$ m $^{-1}$ and injection volume was $10 \mu \mathrm{L}$. The detection was performed at 280 , 350 , and $370 \mathrm{~nm}$. The twelve standard compounds were run for comparable detection and optimized. All samples were assayed in triplicate. All quantitative data were explained by analysis software.

\section{MOLECULAR DOCKING TEST}

The conformation of ligands bound in the active site of estrogen receptor alpha (ER $\alpha)$ and beta $(\operatorname{ER} \beta)$ were used as targets for the prediction of estrogenic activity of the phytoestrogen, which was determined using automated docking simulations. The protein structure files (PDB ID:1GWR for ER $\alpha$ and 3OLS for ER $\beta$ ) were obtained from the Protein Data Bank (www.rcsb.org/pdb). The proteins were edited using Discovery Studio by removing the heteroatoms and water molecules. Phytoestrogen ligands were geometrically optimized using Avogadro. AutoDock Tools 4.0 was employed, using the Lamarckian genetic algorithm method, for docking preparation. Docking calculations were conducted using Command 
Prompt with assigned Autodock4 and Autogrid4. All torsions were allowed to rotate during docking processes. The grid map was centered at particular residues of the protein which were generated using AutoGrid.

\section{STATISTICAL ANALYSIS}

The estrogenic activities were statistically analyzed using SPSS software version 22.0 for Windows. Statistical analyses were performed by one-way analysis of variance (ANOVA) followed by Least Significant Difference (LSD) test or Student's t-test for normally distributed data, while Kruskal-Wallis test using Bonferroni adjustment or Mann Whitney U test was used to analyze the nonnormally distributed data. Pearson product-moment correlation test was used to determine the correlation of the data. All values were expressed as mean \pm standard deviation (SD).

\section{RESULTS AND DISCUSSION}

\section{CYTOTOXICITY TEST}

The cytotoxicity test was conducted in order to choose the appropriate concentrations of extracts to be used in the E-screen assay. As seen in Table 1, the n-hexane extract at a concentration of $10 \mu \mathrm{g} \mathrm{mL}^{-1}$ showed significantly high toxicity $(\mathrm{p}<0.05)$. Hence, the suitable maximum concentration for all of the extracts was $1 \mu \mathrm{g} \mathrm{mL}^{-1}$. All of the samples at this concentration were considered nontoxic and were expected not to interfere with the results of the proliferative effect of the samples in the E-screen assay.

TABLE 1. Cytotoxicity test results of P. pellucida extracts using WST-1 cell proliferation assay

\begin{tabular}{lccc}
\hline \multicolumn{3}{c}{$\%$ cytotoxicity (mean $\pm \mathrm{SD})$} \\
\hline \multicolumn{1}{c}{ Group of extracts } & $0.1 \mu \mathrm{g} \mathrm{mL}^{-1}$ & $1 \mu \mathrm{g} \mathrm{mL} L^{-1}$ & $10 \mu \mathrm{g} \mathrm{mL}^{-1}$ \\
\hline N-hexane extract & $66.10 \pm 1.30$ & $100.21 \pm 15.31$ & $11.47 \pm 1.26^{* *}$ \\
Ethyl acetate extract & $100.62 \pm 7.85$ & $107.69 \pm 4.75$ & $130.40 \pm 32.46$ \\
Ethanol extract & $101.25 \pm 33.16$ & $105.45 \pm 34.92$ & $134.24 \pm 48.14$ \\
Water extract & $110.10 \pm 20.37$ & $133.23 \pm 32.66$ & $146.98 \pm 38.30^{*}$ \\
\hline
\end{tabular}

$*(\mathrm{p}<0.05), * *(\mathrm{p}<0.01)$ compared to control

\section{E-SCREEN ASSAY}

As depicted in Figure 1(a), each extract type has varying levels of estrogenic activity. Overall, the water extracts showed the highest estrogenic activity, while the n-hexane extracts the lowest. Estrogenic activity may support the antiosteoporosis activity of $P$. pellucida. Estrogen can downregulate TNF- $\alpha$, IL-1, IL-6, and prostaglandin- $\mathrm{E}_{2}$ that increase bone resorption by increasing receptor activator of NF- $\kappa \mathrm{B}$ ligand or osteoclasts differentiating factor and decreasing osteoprotegerin secretion. Estrogen can also upregulate TGF- $\beta$, which acts as an inhibitor of bone resorption by decreasing activity and increasing apoptosis of osteoclasts (Riggs 2000).

The n-hexane, ethyl acetate, and ethanol extracts at a concentration of $0.01-1 \mu \mathrm{g} \mathrm{mL}^{-1}$ showed a partial agonist effect (RPE\% 25-80\%). Partial agonist estrogenic agents (antiestrogens) are an interesting topic. Partial agonists can work selectively, and can also play the role of an antagonist when a full agonist is present. This agent may either stimulate or block certain genes (MacGregor \& Jordan 1998), resulting in phytoestrogens' ability to act not only as an estrogen-like compound but also able to antagonize the undesirable effect of estrogen such as proliferation in cancer. These properties make P. pellucida attractive targets for further characterization of their estrogenic activity.

Among the test samples, only the water extract showed a full agonist effect (RPE\% $>80 \%$ ). The estrogenic activity of the $P$. pellucida extracts occurred in a polaritydependent manner. This finding suggests that the more polar the sample, the higher its estrogenic effect. The result supported a previous study that found the polar to mid-polar compounds mainly contribute to estrogenic activity through ERs (Creusot et al. 2013). This issue correlates with how a ligand binds to the ERs. Even 
tamoxifen, a known antiestrogenic agent, undergoes bioactivation to become hydroxytamoxifen, which is

more polar, giving it a higher affinity to the ERs.

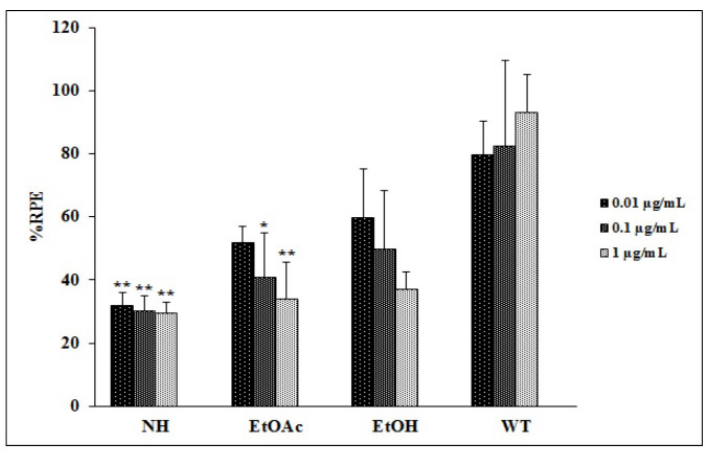

(a)

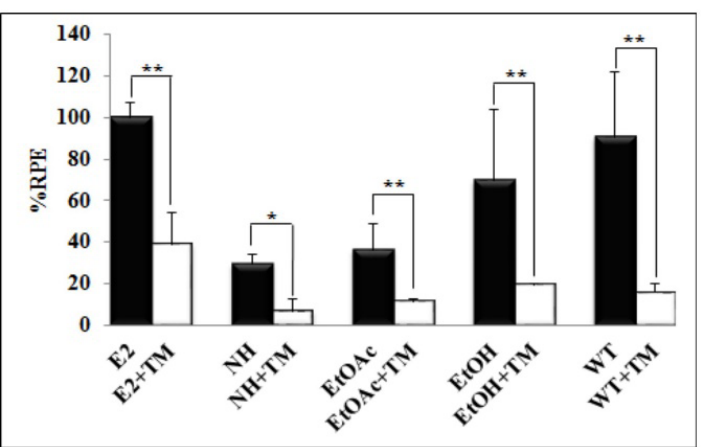

(b)

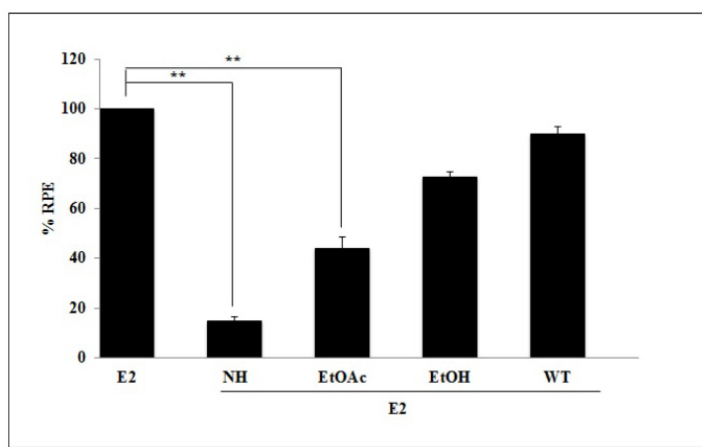

(c)

FIGURE 1. The estrogenic, mechanism, and antiestrogenic studies of Peperomia pellucida extracts. a: estrogenic test: estrogenic activity of four types of extracts from $P$. pellucida with $\mathrm{E}_{2} 10^{-9} \mathrm{M}$ as standard control; b: mechanism study: estrogenic activity of the extracts alone and together with tamoxifen as antiestrogenic agent (extract $0.1 \mu \mathrm{g} \mathrm{mL}^{-1} ; \mathrm{E}_{2} 10^{-9} \mathrm{M} ; \mathrm{TM} 10^{-6}$ $\mathrm{M})$; c: antiestrogenic test: estrogenic activity of $17 \beta$-estradiol given alone and together with extracts at a concentration of $0.1 \mu \mathrm{g} \mathrm{mL}^{-1}\left(\mathrm{E}_{2} 10^{-11} \mathrm{M}\right)$. “*” $(\mathrm{p}<0.05)$, “**” $(\mathrm{p}<0.01)$. RPE, relative proliferative effect; $\mathrm{NH}, \mathrm{n}$-hexane extract; EtOAc, ethyl acetate extract; EtOH, ethanol extract; WT, water extract; E2, 17ß-estradiol; TM, tamoxifen

The E-screen assay was also performed to analyze the estrogenic mechanism of the P. pellucida extracts. The proliferative effect of estradiol as a standard estrogenic agent and individual test extracts were compared with the proliferative effect of each of those estrogenic agents in combination with tamoxifen as the antagonist agent.

The result (Figure 1(b)) shows that the \%RPE of estradiol decreased significantly when in combination with tamoxifen. The significant decrease of estradiol's proliferative effect was also shown in other test groups. This result indicates that the estrogenic activity of the extracts may be mediated by the same mechanism of action as estradiol's, which can be blocked by tamoxifen. It is a classical ligand-dependent mechanism. The classical ligand-dependent mechanism is one of the several mechanisms exerted by estrogen (Hall et al. 2001; Yaşar et al. 2016). In this mechanism, estrogen binds to 
ERs, which induces the dimerization of the receptor and binding to specific DNA response elements (EREs) in the target genes' promoters. This finding is in line with the previous study. The compound named 7,8 -trans- $8,8^{\prime}$-trans7',8'-cis-7,7'-bis(5-methoxy-3,4-methylenedioxyphenyl)8-acetoxymethyl-8'- hydroxy methyl tetrahydrofuran which was isolated from $P$. pellucida by Xu et al. (2006), demonstrated its estrogen-like activity through binding with ER and was entirely blocked by an ER antagonist.

The ligand-dependent mechanism of estrogen, especially in ER $\alpha$, is mediated by two separate nonacidic activation domains, namely a constitutive activation function-1 (AF-1), located inside the amino-terminus (A/B domain), and also a hormone-dependent AF-2, located in the ligand-binding domain. In this case, tamoxifen inhibits AF-2 that contributes to its antagonist action in ER $\alpha$. This agent also acts as an antiestrogen in the breast due to its competitive inhibition against estrogen and recruitment of corepressors (Berry et al. 1990; Peng et al. 2009; Shang \& Brown 2002).

Besides estrogenic activity, antiestrogenic activity was also analyzed in this study. Antiestrogenic activity was identified by comparing the \%RPE of each sample and the \%RPE of a combination of sample and estradiol. In this case, estradiol was assumed to have 100\% RPE. Hence, if the \%RPE of the combination group is lower than $100 \%$, the sample is considered to have antiestrogenic activity.

Based on Figure 1(c), the n-hexane and ethyl acetate extracts have antiestrogenic activity. The antiestrogenic levels of the n-hexane and ethyl acetate extracts are about 91.03 and $56.04 \%$, respectively. This finding is similar to the results of the estrogenic activity test, i.e. the antiestrogenic activity occurs in a polarity-dependent manner.

The n-hexane extract showed low estrogenic activity and significantly high antiestrogenic activity compared with standard $17 \beta$-estradiol in $10^{-9} \mathrm{M}$ (RPE\% 100\%). This high antiestrogenic activity is analogous to the activity of a pure antagonist agent. Estrogen antagonist agents block nuclear uptake of the receptor and then inhibit its nucleocytoplasmic shuttling. In this case, the antiestrogenic agent can bind to ER to form complexes and then bind to EREs, resulting in the inactivation of the transcriptional unit, provoking the destruction of the ER in breast cancer cells. A pure antiestrogenic agent can cause the accumulation of the newly synthesized receptor in the cytoplasm and inhibits its transport to the nucleus, whereas the receptor is retained in the nucleus in the presence of partial antiestrogens such as tamoxifen. The receptor complex that is paralyzed will be rapidly destroyed (Dauvois et al. 1993) and the complete destruction of the ERs will inhibit any estrogen-induced events from occurring.

\section{PHYTOCHEMICAL SCREENING}

Phytochemical screening was conducted to know the types of compounds present in the test extracts. The results show that the samples contained varying types of compounds. The dry plant sample had all types of compounds, except quinones, and steroids. It was observed that the n-hexane extract contained alkaloids, steroids and triterpenoids; the ethyl acetate extract contained only flavonoids and steroids; the ethanol extract contained all types of test compounds; while the water extract contained flavonoids, saponins, tannins, and triterpenoids. This finding suggests that there are many types of compounds that may have influenced the level of estrogenic activity of the test extracts. The compounds may work individually, antagonistically or synergistically as described in other studies (Khan et al. 2004; Mariotti et al. 2011).

\section{DETERMINATION OF TOTAL FLAVONOID CONTENT}

Since phytoestrogen mainly consists of flavonoid groups (Kühnau 1976), the total flavonoid content within each of the test extract was calculated. The total flavonoid content varied among the four types of extracts. The values of the n-hexane extract, the ethyl acetate extract, the ethanol extract and the water extract were $16.36 \pm 0.23$, $35.90 \pm 0.49,10.84 \pm 0.11$, and $6.70 \pm 0.32 \mu \mathrm{g} \mathrm{QE} / 100$ mg extract, respectively. Statistical calculation showed that the level of total flavonoid content does not significantly correlate with either the estrogenic or the antiestrogenic activity of the samples. The activity may be produced not only by flavonoids but also by the interaction of two or more groups of compounds, as mentioned.

\section{DETECTION AND QUANTIFICATION OF PHYTOESTROGEN COMPOUNDS IN THE P. pellucida EXTRACTS}

Phytochemical tests were conducted to investigate the presence of specific phytoestrogen compounds in the extracts. As common and well-known phytoestrogen compounds, quercetin and stigmasterol were detected in the P. pellucida extracts (Figure 2). This finding supports previous studies that have successfully isolated these compounds from P. pellucida (Hartati et al. 2015; Kurniawan et al. 2016). 
<smiles></smiles>

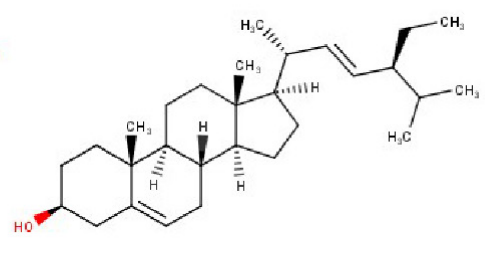

(b)

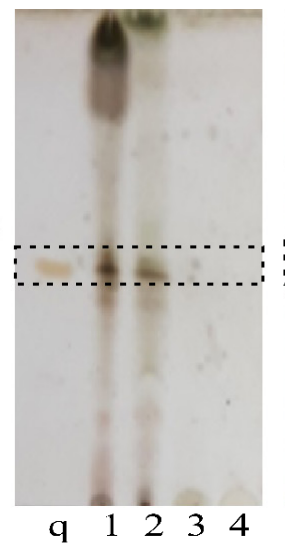

(c)

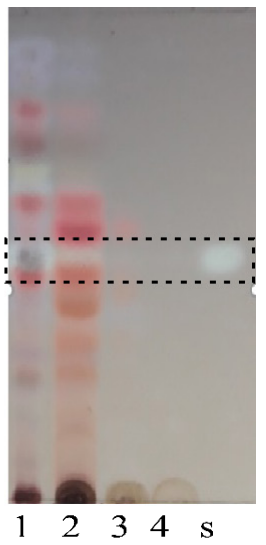

(d)

\begin{abstract}
FIGURE 2. Detection of quercetin and stigmasterol in the test extracts using TLC. a) chemical structure of quercetin; b) chemical structure of stigmasterol; c) detection of quercetin using chloroform, ethyl acetate, and formic acid in the volume ratio 6:4:0.1 as the mobile phase; $d$ ) detection of stigmasterol using n-hexane and ethyl acetate in the volume ratio 7:3 as the mobile phase. Spots were detected under UV light at $366 \mathrm{~nm}$ after spraying with $10 \%$ sulfuric acid. The dotted-line show the possibility of quercetin and stigmasterol $(\mathrm{q}=$ quercetin, $\mathrm{s}=$ stigmasterol, $1=$ n-hexane extract, 2 = ethyl acetate extract, $3=$ ethanol extract, $4=$ water extract)
\end{abstract}

As depicted on Figure 2(c) and 2(d), the presence of quercetin and stigmasterol were detected especially in the n-hexane and the ethyl acetate extract, which had high antiestrogenic activity. This finding suggests that the compounds may be correlated to the antiestrogenic activity of the extracts. Previous studies have reported similar results. Using the same method, quercetin was found to be able to significantly suppress the proliferation of MCF-7 cell as ERs antagonists (Resende et al. 2013). Another study also supports this finding (Miodini et al. 1999). An in vivo test has shown that it can exacerbate breast tumors induced by estradiol, however, this is not due to its estrogenic activity (Singh et al. 2010). The estrogenic and antiestrogenic activity of quercetin have been found to follow a dose-dependent manner, similar to genistein, a well-known phytoestrogen. Quercetin acts as an antagonist at high doses. Furthermore, other flavonoids, including daidzein and luteolin, have also been found to have an antiestrogenic effect (Han et al. 2002).

Stigmasterol as a phytosterol compound is known to be a weak SERM. $\beta$-sitosterol, a phytosterol, can competitively bind to both ERs with an equivalent affinity (Gutendorf \& Westendorf 2001). It showed moderate stimulation toward the growth of the MCF-7 cell line, but inhibited the growth of estrogen-responsive human breast cancer xenografts in a test using mice and also failed to increase the uterine weight as a marker of estrogenic activity (Baker et al. 1999; Ju et al. 2004; Sakamoto et al. 2010).

As the extract with the highest estrogenic activity, the water extract was analyzed further to determine its active compounds. Among twelve standard compounds used in this study, the presence of apigenin and apigetrin was successfully confirmed in the water extract through the combination of TLC-D (Figure 3) and HLPC (Table 2) analysis. The presence of apigetrin in P. pellucida is reported in this study for the first time.

According to Figure 3(a), the standard apigenin had an Rf of 0.42 with an area of 5813.3 AU. The water extract was found to have same Rf, with an area of 2547.4 AU or $36.10 \%$ of the spotted solution. Meanwhile, the standard apigetrin has an Rf of 0.90 with area 13768.2 AU. The water extract was found to have the same Rf with an area of $9246.6 \mathrm{AU}$ or $31.66 \%$ of the spotted solution (Figure 3(b)). 
(a)

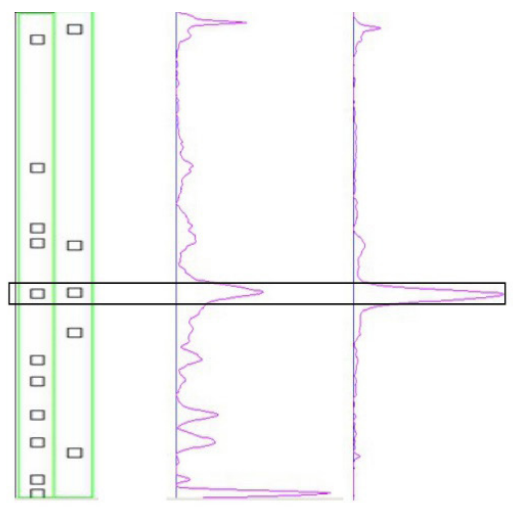

(b)

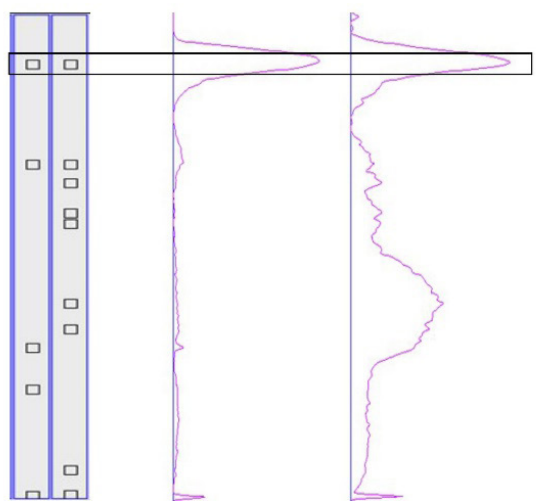

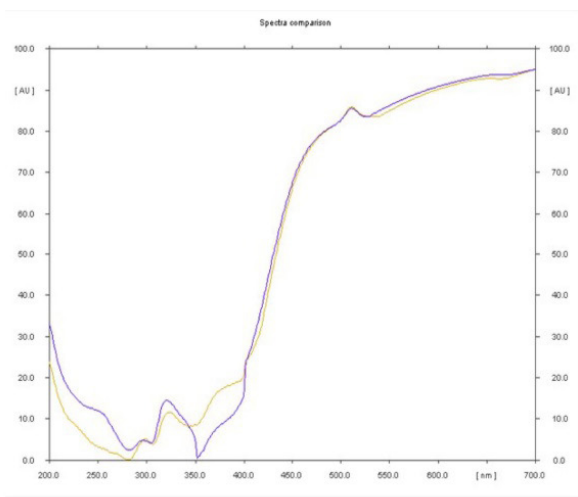

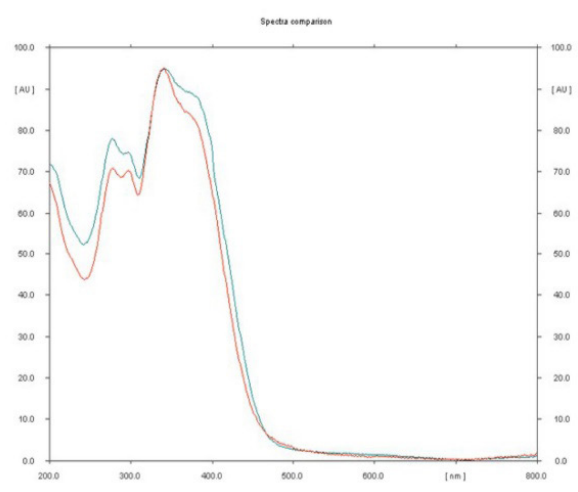

FIGURE 3. Detection of apigenin (a) and apigetrin (b) in water extract of $P$. pellucida using TLC-D: (1) reconstruction of all spots, (2) spectrums, and (3) overlay spectrums of standard and water extract in a certain Rf. Eluent for apigenin is toluen:formic acid:ethyl acetate (6:0.3:4) while for apigetrin 7-O glucoside is ethyl acetate:formic acid:water (5:1:0.5)

TABLE 2. HPLC quantification of flavonoids in P. pellucida extracts

\begin{tabular}{|c|c|c|c|c|}
\hline \multicolumn{2}{|c|}{ Flavonoids } & \multirow{2}{*}{$\begin{array}{c}\text { Standard } \\
\begin{array}{c}\text { Retention time }(\mathrm{min}, \\
\text { mean } \pm \mathrm{SD})\end{array}\end{array}$} & \multicolumn{2}{|c|}{ Water extract } \\
\hline Name & $\begin{array}{l}\text { Detection wave length } \\
\qquad(\mathrm{nm})\end{array}$ & & $\begin{array}{l}\text { Retention time (min, } \\
\text { mean } \pm \text { SD) }\end{array}$ & $\begin{array}{l}\text { Concentration }\left(\mu \mathrm{g} \mathrm{mg} \mathrm{m}^{-1}\right. \\
\text { extract, mean } \pm \mathrm{SD})\end{array}$ \\
\hline Apigenin & 350 & $7.663 \pm 0.013$ & $7.607 \pm 0.057$ & $0.239 \pm 0.076$ \\
\hline Apigetrin & 350 & $5.835 \pm 0.001$ & $5.764 \pm 0.023$ & $1.063 \pm 0.156$ \\
\hline
\end{tabular}

\section{MOLECULAR DOCKING TEST}

A molecular docking simulations were conducted in order to confirm the prediction regarding the involvement of phytoestrogens in the estrogenic and antiestrogenic activity of the . pellucida extracts. The binding affinity of quercetin, stigmasterol, apigenin, and apigetrin for binding to ER $\alpha$ and ER $\beta$ were evaluated in the simulations. The affinities are represented by predicted free energy of binding (Table 3) and visualization of interactions between the ligands and amino acid residues in the binding site. 
TABLE 3. Molecular docking data of estradiol, quercetin, and stigmasterol to estrogen receptors

\begin{tabular}{|c|c|c|c|c|c|c|}
\hline \multirow[b]{2}{*}{ Compounds } & \multicolumn{3}{|c|}{ Hydrogen bonding (ER $\alpha)$} & \multicolumn{3}{|c|}{ Hydrogen bonding (ER $\beta)$} \\
\hline & $\begin{array}{l}\Delta \mathrm{G} \text { bind (kcal } \\
\mathrm{mol}^{-1} \text { ) }\end{array}$ & $\begin{array}{l}\text { Amino acid } \\
\text { residues }\end{array}$ & $\begin{array}{c}\text { H-bond } \\
\text { distance }(\AA)\end{array}$ & $\begin{array}{l}\Delta \mathrm{G} \text { bind (kcal } \\
\mathrm{mol}^{-1} \text { ) }\end{array}$ & $\begin{array}{l}\text { Amino acid } \\
\text { residues }\end{array}$ & $\begin{array}{c}\text { H-bond } \\
\text { distance }(\AA)\end{array}$ \\
\hline \multirow{2}{*}{ Estradiol } & \multirow{2}{*}{-9.55} & GLU 353 & 3.16773 & -9.55 & HIS 475 & 3.14521 \\
\hline & & HIS 524 & 2.94612 & & GLU 305 & 2.45984 \\
\hline \multirow{4}{*}{ Quercetin } & \multirow{4}{*}{-7.93} & GLY 521 & 1.99724 & -8.22 & GLU 305 & 1.73588 \\
\hline & & GLY 521 & 2.09053 & & GLU 305 & 1.86242 \\
\hline & & GLU 353 & 1.83434 & & GLY 472 & 1.93541 \\
\hline & & LEU 387 & 2.06028 & & LEU 476 & 3.07123 \\
\hline \multirow{5}{*}{ Stigmasterol } & \multirow{5}{*}{-9.96} & ALA350 & 2.80111 & & & \\
\hline & & HIS524 & 3.11883 & & & \\
\hline & & ARG394 & 2.75854 & -11.35 & ARG 346 & 2.58623 \\
\hline & & GLU353 & 2.06099 & & GLU 305 & 2.06616 \\
\hline & & GLU353 & 1.99453 & & GLU 305 & 1.81672 \\
\hline \multirow[t]{5}{*}{ Apigenin } & \multirow[t]{5}{*}{-8.14} & GLY521 & 1.73517 & -8.21 & GLU305 & 1.73669 \\
\hline & & LEU387 & 2.1258 & & GLY472 & 1.91247 \\
\hline & & GLU353 & 1.70145 & & ARG346 & 2.22906 \\
\hline & & HIS524 & 2.01543 & & & \\
\hline & & LEU525 & 2.42525 & & & \\
\hline \multirow[t]{5}{*}{ Apigetrin } & \multirow[t]{5}{*}{-6.81} & GLU353 & 1.98727 & -4.47 & GLY472 & 1.98567 \\
\hline & & ARG394 & 2.49958 & & GLU305 & 1.71836 \\
\hline & & ARG394 & 2.30673 & & ARG346 & 2.42321 \\
\hline & & HIS524 & 2.11942 & & ARG346 & 2.24630 \\
\hline & & HIS524 & 2.07982 & & HIS475 & 1.85958 \\
\hline
\end{tabular}

$\Delta \mathrm{G}=$ Gibbs free energy

Based on the molecular docking results, each phytoestrogen compound has a specific preferable binding toward ERs. Both quercetin and stigmasterol, which are found in the n-hexane and ethyl acetate extracts, has a higher binding energy towards ER $\beta$ than towards $\mathrm{ER} \alpha$. These findings were in line with the previous studies (Powers \& Setzer 2015; Triutomo et al. 2016). This finding suggests that both phytoestrogens have a higher antiestrogenic activity than estrogenic activity.

Apigenin, which was found in the water extract, showed the similar binding profile with quercetin and stigmasterol. This finding also in line with the previous studies (Kuiper et al. 1998; Powers \& Setzer 2015). On the contrary, apigetrin, which was found and firstly reported presents in the water extract, has higher binding energy towards ER $\alpha$ than ER $\beta$. The result was suggesting that the compound tends to have estrogenic activity. Even though the result related to apigetrin did not support the previous study (Powell et al. 2012), all of the compounds analyzed in this study have demonstrated their beneficial effects on osteoporosis condition (Gabay et al. 2010; Goto et al. 2015; Kim et al. 2015a; Oršolić et al. 2018). Further advance research needs to be performed to clarify these findings and find the other compounds that support the activity of water extract. 


\section{CONCLUSION}

In conclusion, each type of extract from $P$. pellucida exerts differing estrogenic activity profiles depending on its polarity and the presence of certain phytoestrogens. The estrogenic activities may be mediated by a classical ligand-dependent mechanism. Since the ethyl acetate extract showed a partial agonist effect even though it contains phytoestrogen high flavonoids content, it may contain other interesting compounds that help boost its estrogenic activity. Meanwhile, the water extract showed promising estrogenic activity that can support its antiosteoporosis activity. It contains compounds such as apigenin and apigenin 7-O glucoside, which are phytochemical compounds that may be responsible for the estrogenic activity. Therefore, we have been doing further investigation related to these findings. Future studies in animal models are also warranted to better define the estrogenic efficacy and safety of extracts from P. pellucida.

\section{ACKNOWLEDGEMENTS}

Part of this research was funded by the PMDSU scholarship from the Ministry of Research, Technology and Higher Education of the Republic of Indonesia and Professor Kyu Hyuck Chung. The authors extend their sincere thanks to all of the Prevent Pharm Laboratory members, School of Pharmacy, Sungkyunkwan University for their technical assistance and advice. The authors also would like to say thank you to Ms. Audrey Amira Crystalia, LPPM, and Graduate School of ITB for their help in the language editing process.

\section{REFERENCES}

Baker, V.A., Hepburn, P.A., Kennedy, S.J., Jones, P.A., Lea, L.J., Sumpter, J.P. \& Ashby, J. 1999. Safety evaluation of phytosterol esters part 1 assessment of oestrogenicity using a combination of in vivo and in vitro assays. Food and Chemical Toxicology 37(1): 13-22.

Berry, M., Metzger, D. \& Chambon, P. 1990. Role of the two activating domains of the oestrogen receptor in the cell-type and promoter-context dependent agonistic activity of the anti-oestrogen 4-hydroxytamoxifen. EMBO Journal 9: 2811-2818.

Burns, K.A. \& Korach, K.S. 2012. Estrogen receptors and human disease: An update. Archives of Toxicology 86(10): 1491-1504.

Creusot, N., Budzinski, H., Balaguer, P., Kinani, S., Porcher, J.M. \& Aït-Aïssa, S. 2013. Effect-directed analysis of endocrinedisrupting compounds in multi-contaminated sediment: Identification of novel ligands of estrogen and pregnane $\mathrm{X}$ receptors. Analytical and Bioanalytical Chemistry 405(8): 2553-2566.
Dauvois, S., White, R. \& Parker, M.G. 1993. The antiestrogen ICI 182780 disrupts estrogen receptor nucleocytoplasmic shuttling. Journal of Cell Science 106(4): 1377-1388.

Gabay, O., Sanchez, C., Salvat, C., Chevy, F., Breton, M., Nourissat, G., Wolf, C., Jacques, C. \& Berenbaum, F. 2010. Stigmasterol: A phytosterol with potential anti-osteoarthritic properties. Osteoarthritis and Cartilage 18(1): 106-116.

Goto, T., Hagiwara, K., Shirai, N., Yoshida, K. \& Hagiwara, H. 2015. Apigenin inhibits osteoblastogenesis and osteoclastogenesis and prevents bone loss in ovariectomized mice. Cytotechnology 67(2): 357-365.

Gutendorf, B. \& Westendorf, J. 2001. Comparison of an array of in vitro assays for the assessment of the estrogenic potential of natural and synthetic estrogens, phytoestrogens and xenoestrogens. Toxicology 166(1-2): 79-89.

Hall, J.M., Couse, J.F. \& Korach, K.S. 2001. The multifaceted mechanisms of estradiol and estrogen receptor signaling. Journal of Biological Chemistry 276(40): 36869-36872.

Han, D.H., Denison, M.S., Tachibana, H. \& Yamada, K. 2002. Relationship between estrogen receptor-binding and estrogenic activities of environmental estrogens and suppression by flavonoids. Bioscience, Biotechnology, and Biochemistry 66(7): 1479-1487.

Harborne, A.J. 1998. Phytochemical Methods a Guide to Modern Techniques of Plant Analysis. 3rd ed. Netherlands: Springer Science \& Business Media. pp. 16-29.

Hartati, S., Angelina, M., Dewiyanti, I. \& Meilawati, L. 2015. Isolation and characterization compounds from hexane and ethyl acetate fractions of Peperomia pellucida L. Journal of Tropical Life Science 5(3): 117-122.

Ju, Y.H., Clausen, L.M., Allred, K.F., Almada, A.L. \& Helferich, W.G. 2004. Beta-sitosterol, beta-sitosterol glucoside, and a mixture of beta-sitosterol and beta-sitosterol glucoside modulate the growth of estrogen-responsive breast cancer cells in vitro and in ovariectomized athymic mice. The Journal of Nutrition 134(5): 1145-1151.

Kartika, I.G.A.A., Riani, C., Insanu, M., Eljabbar, L.F.D. \& Adnyana, I.K. 2018. Sasaladaan (Peperomia pellucida [L.] Kunth.) extracts improve trabecular bone microarchitecture in ovariectomy-induced osteoporotic rats. International Journal of Green Pharmacy (IJGP) 12(04): 1-6.

Khalid, A.B. \& Krum, S.A. 2016. Estrogen receptors alpha and beta in bone. Bone 87: 130-135.

Khan, F., Peter, X.K., Mackenzie, R.M., Katsoulis, L., Gehring, R., Munro, O.Q., van Heerden, F.R. \& Drewes, S.E. 2004. Venusol from Gunnera perpensa: Structural and activity studies. Phytochemistry 65(8): 1117-1121.

Kim, D.H., Moon, Y.S., Park, T.S. \& Son, J.H. 2015a. Serotonins of safflower seeds play a key role in anti-inflammatory effect in lipopolysaccharide-stimulated RAW 264.7 macrophages. Journal of Plant Biotechnology 42(4): 364-369.

Kim, H.R., Lee, J.E., Jeong, M.H., Choi, S.J., Lee, K. \& Chung, KH. 2015b. Comparative evaluation of the mutagenicity and genotoxicity of smoke condensate derived from Korean cigarettes. Environmental Health and Toxicology 30: e2015014. 
Kühnau, J. 1976. The flavonoids. A class of semi-essential food components: Their role in human nutrition. World Review of Nutrition and Dietetics 24: 117-191.

Kuiper, G.G.J.M., Lemmen, J.G., Carlsson, B., Corton, J.C., Safe, S.H., Saag, P.T., Burg, B. \& Gustafsson, Å. 1998. Interaction of estrogenic chemicals and phytoestrogens with estrogen receptor $\beta$. Endocrinology 139(10): 4252-4263.

Kurniawan, A., Saputri, F., Rissyelly, Ahmad, I. \& Mun'im, A. 2016. Isolation of angiotensin converting enzyme (ACE) inhibitory activity quercetin from Peperomia pellucida. International Journal of PharmTech Research 9(7): 115-121.

Lecomte, S., Demay, F., Ferrière, F. \& Pakdel, F. 2017. Phytochemicals targeting estrogen receptors: Beneficial rather than adverse effects? International Journal of Molecular Sciences 18(7): 1380-1400.

MacGregor, J.I. \& Jordan, V.C. 1998. Basic guide to the mechanisms of antiestrogen action. Pharmacological Reviews 50(2): 151-196.

Mariotti, K.C., Schmitt, G.C., Barreto, F., Fortunato, R.E., Singer, R.B., Dallegrave, E., Leal, M.B. \& Limberger, R.P. 2011. Evaluation of anti-estrogenic or estrogenic activities of aqueous root extracts of Gunnera manicata L. Brazilian Journal of Pharmaceutical Sciences 47(3): 601-604.

Miodini, P., Fioravanti, L., Fronzo, G.D. \& Cappelletti, V. 1999. The two phyto-oestrogens genistein and quercetin exert different effects on oestrogen receptor function. British Journal of Cancer 80(8): 1150-1155.

Mostrom, M. \& Tim, J.E. 2018. Phytoestrogens - An overview. ScienceDirect topics. 2018. https://www.sciencedirect.com/ topics/agricultural-and-biological sciences/phytoestrogens. Accessed on 21 August 2018.

Nelson, A.W., Tilley, W.D., Neal, D.E. \& Carroll, J.S. 2014. Estrogen receptor beta in prostate cancer: Friend or foe? Endocrine-Related Cancer 21(4): T219-T234.

Ngueguim, F.T., Khan, M.P., Donfack, J.H., Tewari, D., Dimo, T., Kamtchouing, P., Maurya, R. \& Chattopadhyay, N. 2013. Ethanol extract of Peperomia pellucida (Piperaceae) promotes fracture healing by anabolic effect on osteoblasts. Journal of Ethnopharmacology 148(1): 62-68.

Florence, N.T., Huguette, S.T.S., Hubert, D.J., Raceline, G.K., Desire, D.D.P., Pierre, K. \& Theophile, D. 2017. Aqueous extract of Peperomia pellucida (L.) HBK accelerates fracture healing in Wistar rats. BMC Complementary and Alternative Medicine 17(1): 188-196.

Oh, S.M., Ryu, B.T. \& Chung, K.H. 2008. Identification of estrogenic and antiestrogenic activities of respirable diesel exhaust particles by bioassay-directed fractionation. Archives of Pharmacal Research 31(1): 75-82.

Oršolić, N., Jeleč, Z., Nemrava, J., Balta, V., Gregorović, G. \& Jeleč, D. 2018. Effect of quercetin on bone mineral status and markers of bone turnover in retinoic acid-induced osteoporosis. Polish Journal of Food and Nutrition Sciences 68(2): 149-162.

Peng, J., Sengupta, S. \& Jordan, V.C. 2009. Potential of selective estrogen receptor modulators as treatments and preventives of breast cancer. Anti-Cancer Agents in Medicinal Chemistry 9(5): 481-499.
Perez, P., Pulgar, R., Olea-Serrano, F., Villalobos, M., Rivas, A., Metzler, M., Pedraza, V. \& Olea, N. 1998. The estrogenicity of bisphenol A-related diphenylalkanes with various substituents at the central carbon and the hydroxy groups. Environmental Health Perspectives 106(3): 167-174.

Powell, E., Shanle, E., Brinkman, A., Li, J., Keles, S., Wisinski, K.B., Huang, W. \& Xu, W. 2012. Identification of estrogen receptor dimer selective ligands reveals growth-inhibitory effects on cells that co-express ER $\alpha$ and ER $\beta$. PLoS ONE 7(2): e30993.

Powers, C.N. \& Setzer, W.N. 2015. A molecular docking study of phytochemical estrogen mimics from dietary herbal supplements. In Silico Pharmacology 3(4): 1-63.

Putri, C.A., Kartika, I.G.A.A. \& Adnyana, I.K. 2016. Preventive effect of Peperomia pellucida (L.) Kunth herbs on ovariectomy-induced osteoporotic rats. Journal of Chinese Pharmaceutical Sciences 25(7): 546-551.

Resende, F.A., de Oliveira, A.P.S., de Camargo, M.S., Vilegas, W. \& Varanda, E.A. 2013. Evaluation of estrogenic potential of flavonoids using a recombinant yeast strain and MCF7/BUS cell proliferation assay. PLOS ONE 8(10): e74881.

Riggs, B.L. 2000. The mechanisms of estrogen regulation of bone resorption. The Journal of Clinical Investigation 106(10): 1203-1204

Sakamoto, T., Horiguchi, H., Oguma, E. \& Kayama, F. 2010. Effects of diverse dietary phytoestrogens on cell growth, cell cycle and apoptosis in estrogen-receptor-positive breast cancer cells. The Journal of Nutritional Biochemistry 21(9): 856-864.

Shang, Y. \& Brown, M. 2002. Molecular determinants for the tissue specificity of SERMs. Science 295(5564): $2465-$ 2468.

Singh, B., Mense, S.M., Bhat, N.K., Putty, S., Guthiel, W.A., Remotti, F. \& Bhat, H.K. 2010. Dietary quercetin exacerbates the development of estrogen-induced breast tumors in female ACI rats. Toxicology and Applied Pharmacology 247(2): 83-90.

Triutomo, D.H., Miranda, A., Tamba, L.J. \& Lukitaningsih, E. 2016. Estrogenic effect ethanol extract corn silk (stigma maydis) on bone density and histology femur profiles in ovariectomized rats female sprague dawley strain. Indonesian Journal of Cancer Chemoprevention 7(3): 104-109.

Williams, C., Edvardsson, K., Lewandowski, S.A., Ström, A. \& Gustafsson, J.A. 2008. A genome-wide study of the repressive effects of estrogen receptor beta on estrogen receptor alpha signaling in breast cancer cells. Oncogene 27(7): 1019-1032.

Xu, S., Li, N., Ning, M.M., Zhou, C.H., Yang, Q.R. \& Wang, M.W. 2006. Bioactive compounds from Peperomia pellucida. Journal of Natural Products 69(2): 247-250.

Yaşar, P., Ayaz, G., User, S.D., Güpür, G. \& Muyan, M. 2016. Molecular mechanism of estrogen-estrogen receptor signaling. Reproductive Medicine and Biology 16(1): 4-20.

I Gusti Agung Ayu Kartika, Muhamad Insanu, Catur Riani \& I Ketut Adnyana*

School of Pharmacy

Bandung Institute of Technology

40132, Bandung

Indonesia 
Kyu Hyuck Chung

School of Pharmacy

Sungkyunkwan University

Suwon 16419

Republic of Korea
*Corresponding authors; email: ketut@fa.itb.ac.id

Received: 16 November 2019

Accepted: 6 July 2020 